\title{
ARROWHEADS OF THE ŠTRAMBERK TYPE FROM SPYTKOWICE 26 (DISTRICT OF WADOWICE) AGAINST THE BACKGROUND OF THE ENEOLITHIC CHIPPED INDUSTRIES
}

\author{
ROBERT KENIG
}

A u t h o r' s a d d r e s s: Graduate student at Institute of Archeology of the Jagiellonian University, Gołębia 11, 33-332 Kraków; W. Szafer Institute of Botany, Polish Academy of Sciences, Lubicz 46, 31512 Kraków; e-mail: rkenig@gmail.com; ORCID: 0000-0001-5027-1341

A b s t r a c t. This paper presents the Štramberk type arrowheads found during excavations in Spytkowice in 1993 and 2019. They represent a local Eneolithic phenomenon known mostly from the Moravia region and Silesia on both sides of the Polish-Czech border. However, some examples from outside of this area are discussed as well. The main aim is to present them against the background of other artefacts of this type, and against Eneolithic arrowheads in general. The phenomenon in question seems to be intercultural and its origins may be connected with late Lengyel culture groups, although such arrowheads were also found in Funnel Beaker culture contexts and, as suggested by some researchers, may continue even as late as the Early Bronze Age.

K e y w o r d s: Eneolithic, Chipped industry, Lengyel culture, Funnel Beaker culture, arrowheads

\section{INTRODUCTION}

The aim of the research is to present new finds of Štramberk type arrowheads from the site of Spytkowice 26 and discuss their chronology against the background of other Central European finds. The term 'arrowheads of the Śtramberk type' (also: Štramberk-Krnov, Kotouč; after ČECHÁK et al. 2017: 120) is used to describe projectile points often retouched on both sides (it may be edge, surface or mixed retouch), having tangs with characteristic notches on both (or at least on one) sides. The appearance of this type of arrowhead in Europe represents a phenomenon that still eludes easy cultural and chronological interpretation (see discussion below). They are widely known mostly from the area of today's Polish and Czech Silesia, with the highest concentration of finds in the upper Oder basin. There also are several finds known from Slovakia, from other parts of the Czech Republic, and from Lesser Poland.

\section{ब(ब्ब}


The beginnings of this phenomenon are generally linked with the Lengyel culture/ early Funnel Beaker culture (HLS IV/FBC) (JANÁK 2005, ChMielewSKi 2014), and it may have continued even until the Early Bronze Age (Kopacz 2012; Kopacz et al. 2016; KufEl-DiaKowsKa, Bronowicki 2017), although many specimens were found without proper archaeological context. Therefore, the new discoveries from Spytkowice could provide us with important data concerning both distribution and chronology of the Štramberk type arrowheads.

\section{THE SITE}

The archaeological site of Spytkowice 26 (Wadowice district) is situated in the Upper Vistula River valley, near the place where the Skawa River flows into the Vistula. It occupies a small eminence with round exposition and its area can be estimated at 2-3 ha. The first excavations, conducted by S. DrYJA, lasted five seasons (19921996). A total area of $600 \mathrm{~m}^{2}$ was examined, mostly in the southern part of the site, and 36 archaeological features were discovered. The obtained artefacts were attributed by S. DRYJA to several occupation phases: the Mesolithic, the Linear Pottery culture (LPC), the Malice culture, and early Medieval (DrYJA 1997, 1998a, b, c, 2005). The materials were presented in several publications, among them by M. STRYJKOWSKA, who analysed all the artefacts from the 1993 season (STRYJKOWSKA 2010). Aside from this, other publications were only short field reports or concerned only selected groups of artefacts (DRYJA 1998d). The most recent publication (BRZESKA-PASEK et al. 2018) deals with flint materials from the 1994-1996 seasons found in archaeological features. It also provides the dating of 28 features based on ceramic artefacts (although without a detailed technological analysis). It shows a clear predominance of Lengyel-Polgár materials over the LPC (BRZESKA-PASEK et al. 2018, Tab. 1). The authors note a close similarity to some cultural units of the Lengyel-Polgár circle, such as the Modlnica group, although not excluding a possible connection of at least some of the artefacts with the Malice culture, the Wyciąże-Złotniki group, or even with the Ocice group.

In 2019, other archaeological excavations were held in Spytkowice, this time under the management of M. MoskAL-DEL Hoyo. An area in the centre of the site was chosen for examination, and two trenches, totalling 800 square meters in area, were opened. The excavations revealed archaeological features, most of which can preliminary be connected with Modlnica group settlement. Some interpretational problems emerged due to a stratigraphic situation specific to Spytkowice. Below a $30-40 \mathrm{~cm}$ thick layer of humus, a layer of brunification was recorded over almost the entire excavated area (information obtained from R. CZERNIAK; it is a layer that was created by the brunification process under the humus accumulation level - see Pelisiak, GĘBICA 2007: 99). It ranged from a dozen to several dozen centimetres in thickness and was rich in prehistoric artefacts, probably coming from damaged upper parts of anthropogenic features. On the surface of this layer there were medieval features, whilst earlier ones (Younger Bronze Age/Early Iron Age, Neolithic) were discernible only after its 
removal, which allows us to consider the brunification layer as indicating the terminus ante quem for these features.

The preliminary overview of the artefacts obtained in 2019 shows that it was right to connect in the literature the most intensive occupation of site Spytkowice 26 with the Modlnica group of the Lengyel-Polgar Cycle (BrZesKa-PASEK et al. 2018: 147). Apart from that, there were several Linear Pottery Culture artefacts found, and a few fragments of Malice culture pottery. Moreover, it is necessary to mention the presence of features containing materials attributable to the late phase of the Lusatian culture (M. KorCZyŃSKa and P. KowALCZYK-MaTYS, personal information), and two early medieval features.

\section{MATERIALS AND METHODS}

\section{Štramberk type arrowheads from Spytkowice 26}

Three Stramberk type arrowheads have been found in the site. One was discovered by S. DRYJA during 1993 excavations in the layer with artefacts (Fig. 1.1) and was interpreted to be of Mesolithic origin (STRYJKowska 2010: 37). Two arrowheads occurred in the above-mentioned layer of brunification, among several hundred flint, stone, and ceramic artefacts (Figs 1.2 and 1.3). It is also noteworthy that another arrowhead, a triangular one (Fig. 1.4), was found in feature 44, which could be connected with the Modlnica group according to the pottery material found in it. This feature produced the largest number of artefacts of all (around one-quarter of all the artefacts found during season 2019).

Below are descriptions of the Štramberk type arrowheads that were found during the excavations in Spytkowice.

\section{1/93 (Fig. 1.1)}

Bifacial arrowhead, with surface retouch on the ventral side and edge, low angle retouch on the dorsal side. The point is triangular and asymmetrical with a broken tip. It has a negative with a slightly visible step-terminating bending fracture that may indicate it was damaged by impact (KUFEL-DiAKOwSKA, BRONOWICKI 2017: 35). It has an isolated tang, underlined by a slightly marked notch. It is probable that the lack of one of the notches results from the fact that this specimen is broken and could have been repaired later. The tang was formed by a bifacial, edge retouch. On the dorsal side a part of the negative is visible, which suggests that it was made on a blade or a blade-like flake. The raw material is Jurassic flint. The length is approximately $2.75 \mathrm{~cm}$, and the width $1.7 \mathrm{~cm}$.

$$
\text { 129/19 (Fig. 1.2) }
$$

Bifacial arrowhead, with surface retouch on the dorsal side and edge, low angle retouch on the half of the central side. The point is triangular and symmetrical. It has 


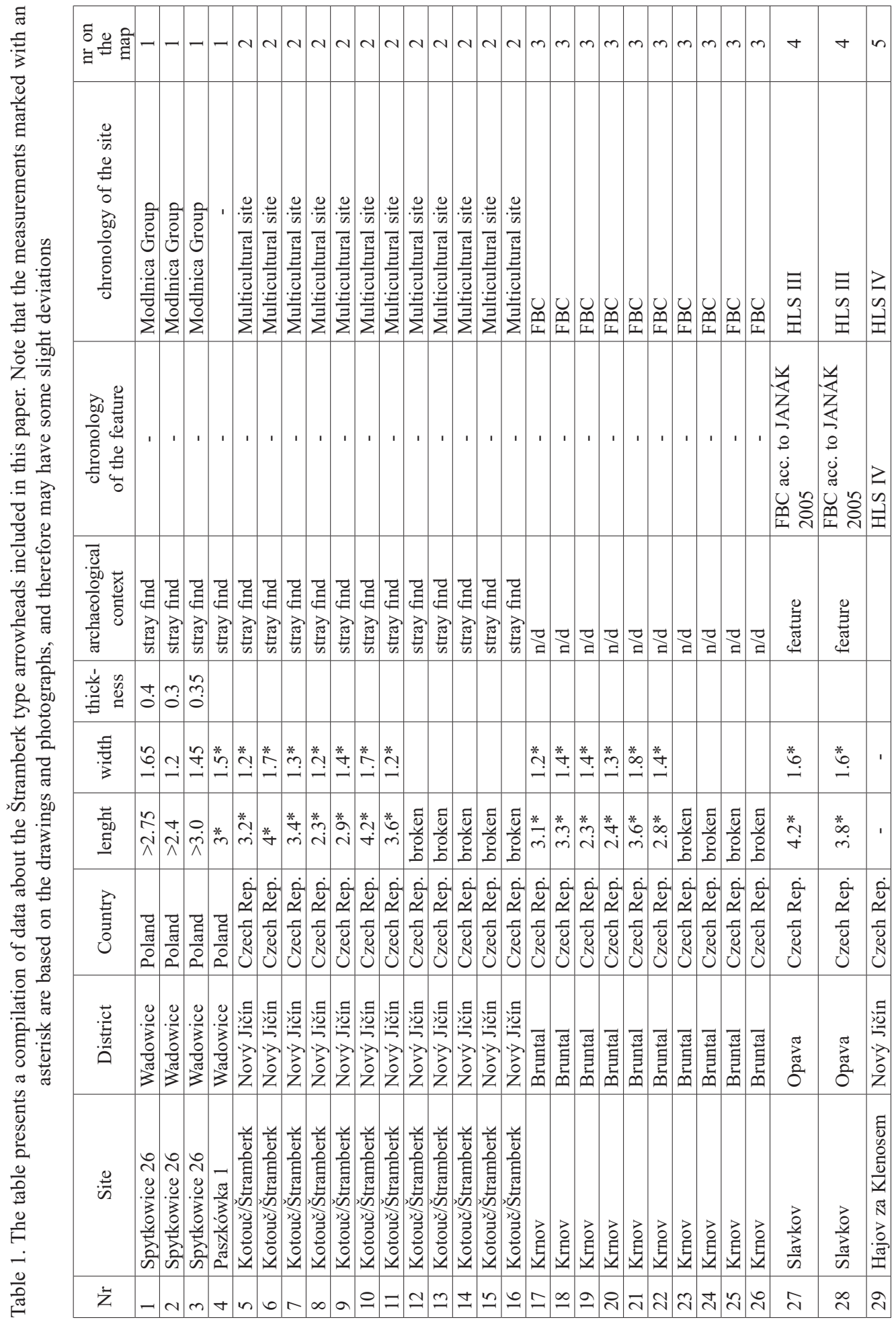




\begin{tabular}{|c|c|c|c|c|c|c|c|c|c|c|c|c|c|c|c|c|c|c|c|c|c|c|c|c|c|}
\hline రే છ శ్ & 6 & $r$ & $\infty$ & $a$ & $a$ & a & 으 & 으 & $=$ & $=$ & $=$ & $=$ & $\simeq$ & $\cong$ & $m$ & $m m$ & $m$ & $m=$ & $\simeq$ & $\because \pm$ & 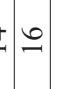 & $=\infty$ & 2 & $a$ & \\
\hline 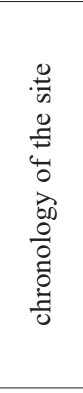 & ' & 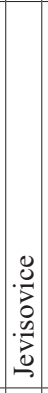 & $\begin{array}{l}\overrightarrow{0} \\
\overrightarrow{00} \\
\overrightarrow{0} \\
\overrightarrow{0} \\
\text { 회 }\end{array}$ & 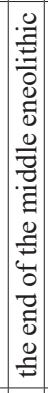 & 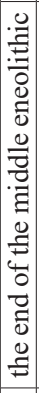 & 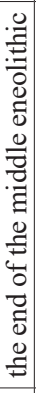 & 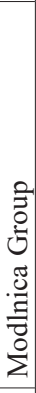 & 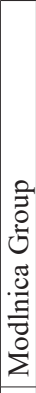 & 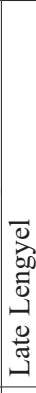 & 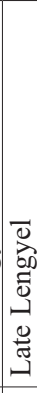 & 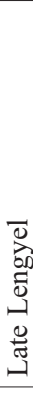 & 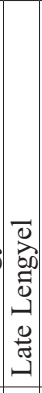 & I & 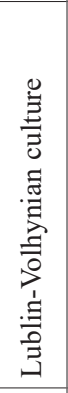 & & & 1 & $\begin{array}{lll}1 & 1\end{array}$ & ' & $\begin{array}{lll}1 & 1\end{array}$ & 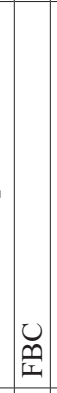 & \begin{tabular}{l|l}
0 & 0 \\
0 & 0 \\
$I$ & \\
\end{tabular} & 足 & 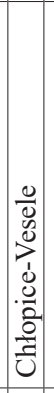 & \\
\hline 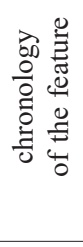 & $\begin{array}{l}\vec{Z} \\
\vec{E} \\
\overrightarrow{\tilde{E}} \\
\stackrel{\vec{E}}{\vec{n}}\end{array}$ & ᄅa & $\stackrel{\Xi}{a}$ & ' & 1 & I & 1 & 1 & 1 & 1 & 1 & 1 & & 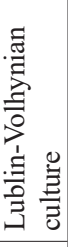 & ' & \begin{tabular}{l|l}
1 & 1
\end{tabular} & 1 & \begin{tabular}{|l|l} 
& 1
\end{tabular} & 1 & \begin{tabular}{l|l}
1 & 1
\end{tabular} & 岱 & 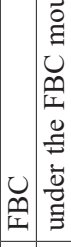 & 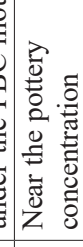 & 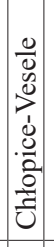 & \\
\hline 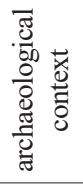 & $\begin{array}{l}\vec{G} \\
\vec{G} \\
\vec{E} \\
\vec{E}\end{array}$ & & & 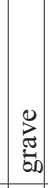 & 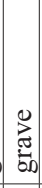 & & & $\stackrel{Z}{a}$ & च & כ) & ב & ב己 & בְ & 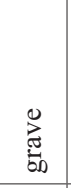 & 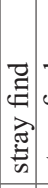 & 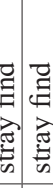 & 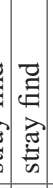 & 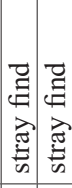 & 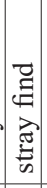 & 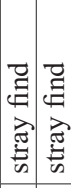 & 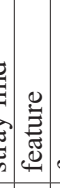 & 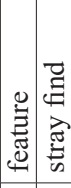 & 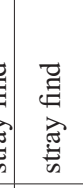 & 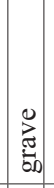 & \\
\hline$\stackrel{\dot{y}}{\circlearrowright}$ & $\stackrel{+}{0}$ & & & वे. & $\begin{array}{l}0 \\
0\end{array}$ & "̊n & & & 草 & & & & ' & & $\hat{\sigma}$ & 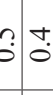 & $\ddot{0}$ & $\because \because$ & $\dot{0}$ & $\begin{array}{lll}n & ? \\
0 & 0\end{array}$ & $?$ & $\stackrel{m}{0}: \stackrel{n}{0}$ & $\hat{\sigma}$ & $\stackrel{\dot{0}}{\dot{0}}$ & \\
\hline$\frac{E}{\frac{E}{3}}$ & $\stackrel{?}{?}$ & $N$ & $\stackrel{*}{\stackrel{*}{\longrightarrow}}$ & $\begin{array}{l}\overrightarrow{0} \\
-\end{array}$ & $\stackrel{2}{-}$ & $\stackrel{f}{-}$ & $\stackrel{n}{-}$ & & $\stackrel{*}{n}$ & $\exists$ & J & g & I & $\stackrel{*}{\stackrel{*}{-}}$ & $\stackrel{\infty}{-}$. & $\because$ & $=$ & 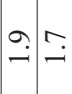 & 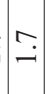 & $\stackrel{\infty}{\infty} \stackrel{n}{-}$ & : & $\stackrel{n}{=}$ & $\sim$ & $\stackrel{\nabla}{-}$ & $n$ \\
\hline $\begin{array}{l}\vec{E} \\
\text { E0 } \\
\text { E }\end{array}$ & $\dot{m}$ & $\stackrel{\sim}{-1}$ & $\stackrel{*}{\stackrel{*}{i}}$ & $\stackrel{\nabla}{\dot{m}}$ & $\stackrel{?}{+}$ & $\hat{\hat{i}}$ & $\hat{i}$ & 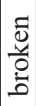 & 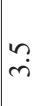 & $m$ & | & 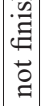 & 1 & $\stackrel{b}{\dot{m}}$ & $m$ & 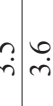 & $\begin{array}{l}\infty \\
i\end{array}$ & $\begin{array}{ll}0 & \infty \\
& \infty \\
\sim\end{array}$ & $\vec{m}$ & $\stackrel{\vec{f}}{\stackrel{?}{*}} \stackrel{?}{+}$ & 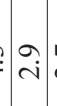 & $\stackrel{\vec{i}}{\stackrel{\sim}{\sim}}$ & $\stackrel{+}{+}$ & $\begin{array}{c}0 \\
\dot{r}\end{array}$ & $\stackrel{\overbrace{}}{+}$ \\
\hline 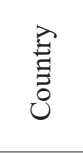 & $\begin{array}{l}\dot{0} \\
\stackrel{\sim}{1} \\
\tilde{0} \\
\tilde{N} \\
\tilde{U}\end{array}$ & 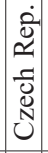 & $\frac{. \pi}{\frac{\pi}{\pi}}$ & 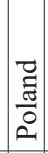 & $\begin{array}{l}\vec{z} \\
\frac{\vec{z}}{0} \\
0\end{array}$ & $\begin{array}{l}\vec{Z} \\
\text { ज्ञ } \\
0 \\
0\end{array}$ & \begin{tabular}{|l}
$\vec{z}$ \\
ज्ञ \\
0 \\
2
\end{tabular} & 胥 & $\begin{array}{l}\bar{Z} \\
\text { ज्ञ } \\
0 \\
2\end{array}$ & $\begin{array}{l}\vec{z} \\
\text { a } \\
0 \\
0 \\
2\end{array}$ & & $\mid \begin{array}{l}\vec{z} \\
\text { ज्ञ } \\
0 \\
0\end{array}$ & & $\begin{array}{l}\vec{E} \\
\frac{\vec{E}}{0} \\
2\end{array}$ & $\begin{array}{l}\bar{z} \\
\bar{\Xi} \\
0 \\
0 \\
0\end{array}$ & 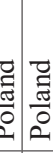 & $\begin{array}{l}\vec{\Xi} \\
\frac{\pi}{0} \\
2\end{array}$ & 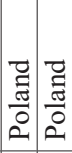 & $\begin{array}{l}\vec{z} \\
\frac{\vec{t}}{0} \\
0\end{array}$ & 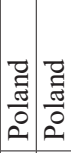 & $\begin{array}{l}\vec{Z} \\
\frac{\vec{J}}{0} \\
0\end{array}$ & 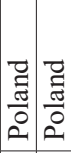 & 点 & 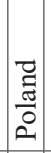 & \\
\hline 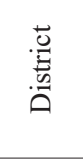 & 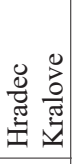 & 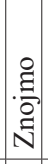 & 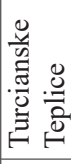 & 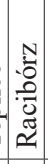 & 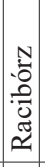 & 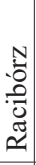 & 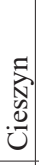 & స్. & 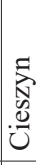 & 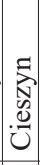 & 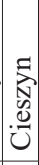 & 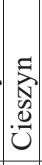 & $\begin{array}{l}N \\
0 \\
0 \\
0 \\
\tilde{0} \\
\simeq\end{array}$ & 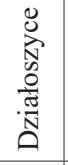 & 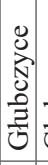 & 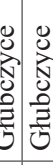 & 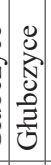 & 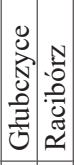 & 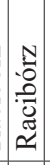 & 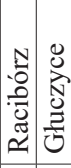 & 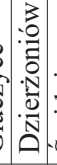 & 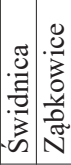 & $\begin{array}{l}\frac{3}{0} \\
\frac{\pi}{0} \\
0 \\
0\end{array}$ & 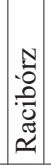 & \\
\hline 总 & 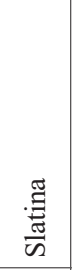 & $\mid$\begin{tabular}{l}
0 \\
\multirow{2}{3}{} \\
0 \\
0 \\
0 \\
0 \\
0 \\
0 \\
0
\end{tabular} & 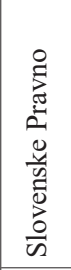 & 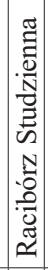 & 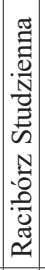 & 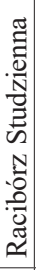 & 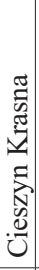 & 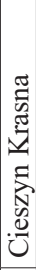 & U & छ् & 节 & 袀 & 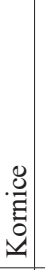 & 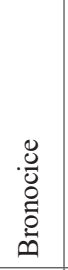 & 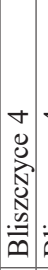 & 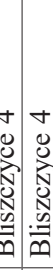 & 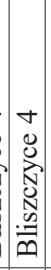 & 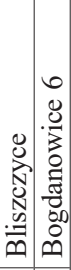 & 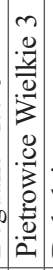 & 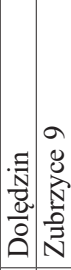 & 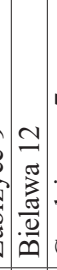 & 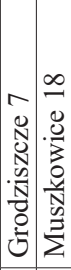 & 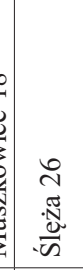 & 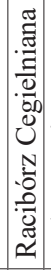 & $\begin{array}{l}\text { F } \\
\text { O } \\
\text { E }\end{array}$ \\
\hline$\dot{z}$ & 이 & $\vec{m}$ & กี & $m$ & & & & & & & 웅 & ‡ & & $\mathscr{q}$ & 寸 & $\begin{array}{l}8 \\
y\end{array}$ & 于 & $\stackrel{\infty}{+} \underset{f}{q}$ & in & $\bar{n} \approx$ & $n$ & in $n$ & in & $n$ & \\
\hline
\end{tabular}



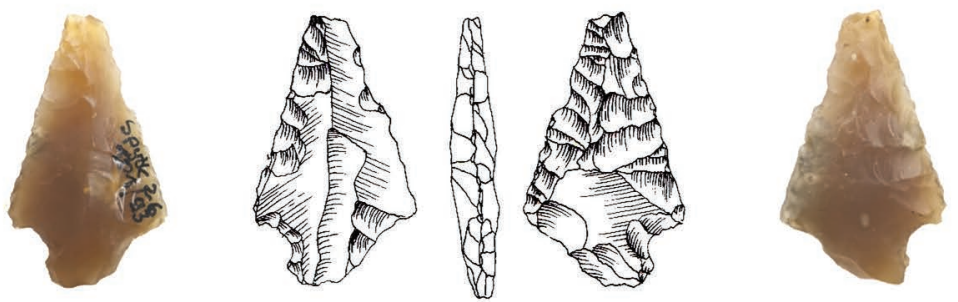

2
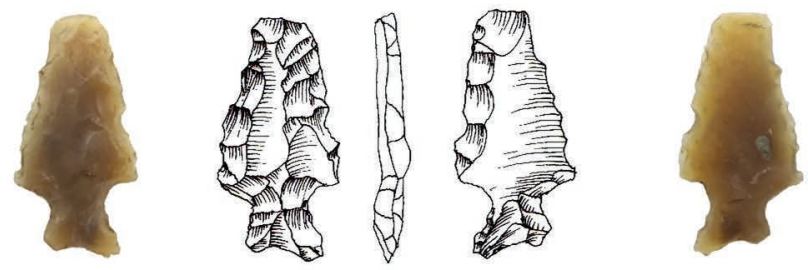

3
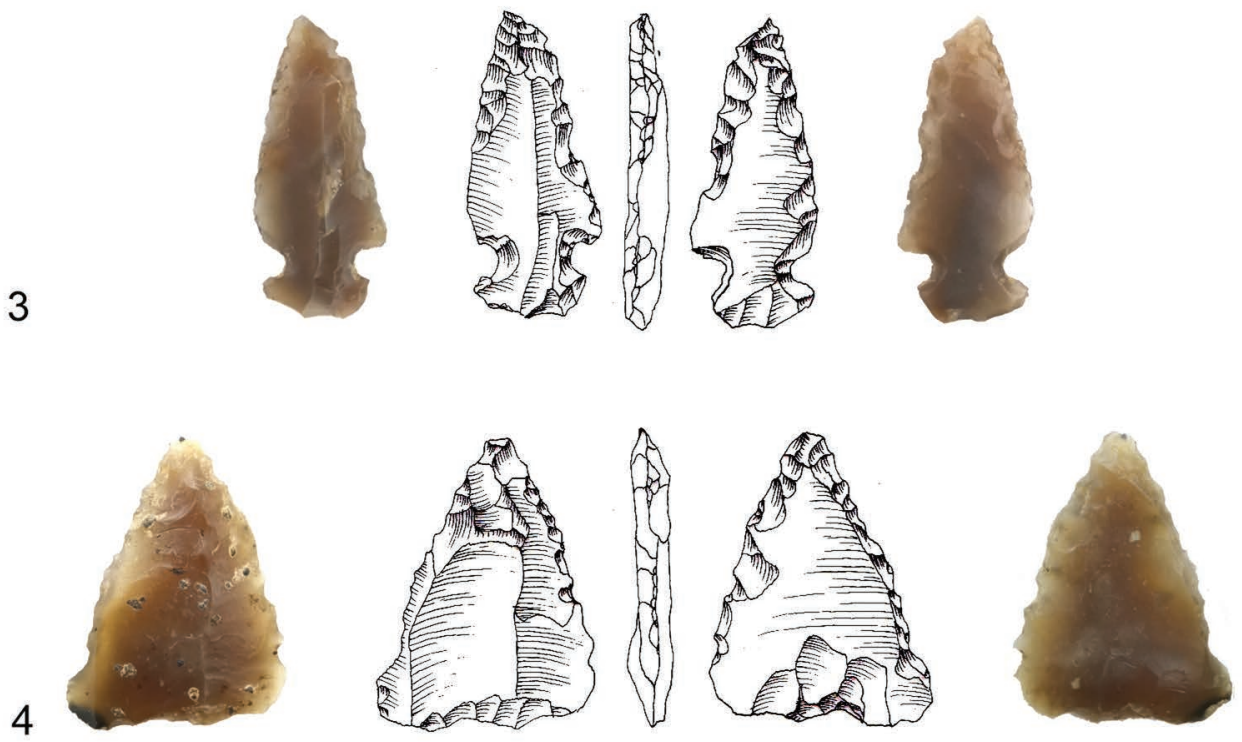

Fig. 1. Štramberk type arrowheads from Spytkowice $26 ; 1-101 / 93 ; 2-129 / 19 ; 3-3027 / 19 ; 4-1638 / 19$. Drawn by J. Mugaj

a broken tip and a negative with characteristic step-terminating bending fracture which may indicate that it was damaged by impact (KUFEL-DIAKOWSKA, BRONOWICKI 2017: 35). A distinct tang is formed by a surface bifacial retouch, with notches on both sides and a crescent-shape ending, a bit similar to a fish-tail. The raw material is a Jurassic flint; the length is over $2.4 \mathrm{~cm}$, and the width $1.2 \mathrm{~cm}$. 
3027/19 (Fig. 1.3)

A bifacial arrowhead, with edge retouch both on the dorsal and ventral sides. The point is leaf-shaped and its tip is broken; a burin-like strike negative is visible, possibly indicative of an impact (SANO 2009: 71, there further literature). On the upper side of the ridge the negative is visible, which indicates that it was made on a blade or a bladelike flake, we can also assume that it was removed from an opposite platform core. The well-formed tang has notches on both sides, is covered with edge retouch, and is broken on one side. The raw material is Jurassic flint; the length is $3.1 \mathrm{~cm}$ and the width $1.4 \mathrm{~cm}$.

Unfortunately, as it was pointed out none of the arrowheads were found in an archaeological feature, so their cultural context cannot be credibly determined directly.

Below, the three Spytkowice arrowheads described above are compared with materials published in the literature. The chronological position of the arrowheads from Spytkowice is discussed based on all finds of this type from the Czech Republic, Slovakia and Poland, known from literature and from unpublished data.

\section{DISCUSSION}

\section{The function of the Stramberk type arrowheads}

The macroscopic analysis of Spytkowice arrowheads could lead only to limited conclusions, and further traseological analysis is necessary. At this stage we could clearly point out that all the three specimens have broken tips, two of them have negatives with typical step-terminating bending fractures, and one has a burin-like strike negative. According to the literature, these traces may be interpreted as impact scars (see for example Kufel-Diakowska, Bronowicki 2017: 35; SAno 2009: 71, there further literature). In the article by B. KUfEL-DiakowsKA and J. BRONOWICKI there are six examples of Neolithic projectile points with broken tips, five of which were interpreted as possibly damaged by impact, and three also have step-terminating bending fractures. This article concerns traseological analysis of 16 tanged arrowheads found in Silesia. Aside from the analysis of the artefacts, the authors also created replicas of the specimens, which were later used for various activities like repeated insertion into and removal from a quiver, or being shot into a wild boar carcass a dozen to a few dozen times (depending on the example). These experiments led to interesting conclusions. The first one, obtained from experiments with replicas, is that these projectile points were distinguished by great durability that certainly compensated for the amount of time necessary for their production. Out of the six specimens that were shot only two developed impact scars, among them one that hit the target 35 times (KuFEl-DiakowsKa, Bronowicki 2017: 36). It turned out that among the 16 specimens analysed, impact traces were the exception rather than the rule (although this might be explained by the abovementioned durability of tanged points), which may indicate intensive use of the Spytkowice specimens. The analysis of the 16 artefacts 
in comparison with their replicas showed that one of the examples was clearly used as a leather perforator, and use-wear traces often occurred on the edges and tips, possibly indicating that the arrowheads hit targets and were pulled out many times. The authors therefore proposed a different functional interpretation of this type of artefact, as daggers used for combat or hunting (KUFEL-DiakowsKA, BRonowicki 2017: 42, 43). Also J. LibERA points out that some of these "leaf-shaped points" (as he calls them) could have been used for a different purpose than only as arrowheads. He mentions the sites dated to the first half of 4 th millennium $\mathrm{BC}$ on the shores of the Bodensee, where such artefacts were found that were clearly used as sickles (organic material was partially preserved there) known as Riedschachen sickles. He also discusses examples where "arrowheads" were used as skin perforators, knives or drills (LiBERA 2001: 42). To consider these theories in the context of the Spytkowice projectile points, it is not enough to rely on the macroscopic analysis alone; it is of course necessary to conduct further traseological research.

\section{Štramberk arrowheads in the Czech Republic, Slovakia and Poland}

In Central Europe there are 24 archaeological sites from which the Štramberk type arrowheads are known (Fig. 2, Tab. 1). As it is known, the type took its name from a settlement on Kotouč hill in the town of Štramberk (Nový Jičín district), in the Czech

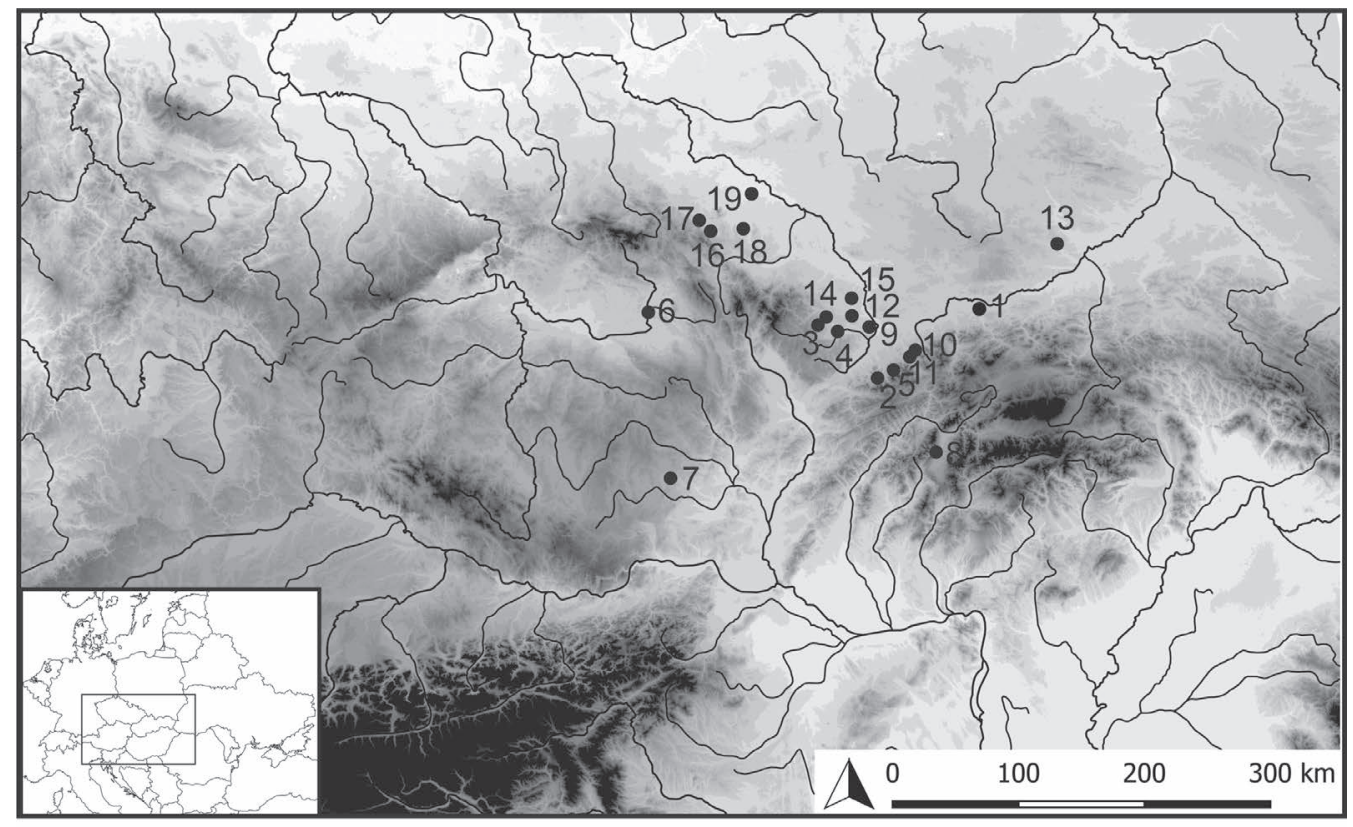

Fig. 2. Sites with the Štramberk type arrowheads mentioned in the text: 1 - Spytkowice 26, Paszkówka 1; 2 - Štramberk; 3 - Krnov, Bliszczyce; 4 - Slavkov; 5 - Hájov-Za Klenosem; 6 - Slatina; 7 - Grešlové Mýto; 8 - Slovenské Pravno; 9 - Racibórz-Studzienna, Racibórz Cegielniana; 10 - Cieszyn-Krasna, 11 - Gumna; 12 - Kornice, Pietrowice Wielkie; 13 - Bronocice; 14 - Bogdanowice 6, Zubrzyce 9; 15 - Dolędzina; 16 Bielawa 12; 17 - Grodziszcze 7; 18 - Muszkowice 18; 19 - Ślęża 26. Made on a map drawn by J. Jędrysik 
Republic. It was a hilltop settlement, and archaeological material was found there as early as the $19^{\text {th }}$ century, but the most important research (of a rescue character, due to limestone exploitation) took place in the middle of the $20^{\text {th }}$ century. A portion of the artefacts recovered at that time were published in 1960 by B. KLIMA (cited after: VeNCL 1964). He connected a series of arrowheads made of flint and chert with the upper Palaeolithic, based on the fact that some of them were covered with patina. A polemic article was then published by S. VENCL (1964), who argued that patina could have developed on younger artefacts as well. Moreover, he pointed out 17 other sites where analogous projectile points were found alongside artefacts of a younger stone-age chronology. In summary, he proposed that these arrowheads should be connected with the late Neolithic or Eneolithic. The Kotouč site revealed a multicultural stratigraphic sequence. Its analysis shows the existence of several occupational phases at the turn of the late Neolithic and Eneolithic (JANÁK 1998). V. Janák admits a possibility that the projectile points in question have late Lengyel chronology, although he does not make a clear statement in this respect (JANÁK 2005: 151, also: ŠIKULOvÁ, ZÁPOTOCKÝ 2010: 407).

The next site where arrowheads of the Štramberk type were found is Krnov (Bruntal district). They were published as early as the 1930s. The site is situated on Přední Cvilínský Kopec, a hill reaching $441 \mathrm{~m}$ a.s.l. It is a Funnel Beaker culture settlement with Baden influences in its younger phase (JANÁK 2005: 168). Archaeological research was carried out in the site before the Second World War by K. Schirmeisen. Apart from excavating 17 features in 1934-35, he also collaborated with local people, which allowed him to obtain a significant number of artefacts found by the residents over the years. Among them were characteristic tanged arrowheads with notches (SCHIRMEISEN 1936: Abb. 2; VenCL 1964: 51).

Projectile points of the Štramberk type were also found in archaeological sites at Slavkov (Opava district) and Hájov - za Klenosem (Nový Jičín district). In the former site, arrowheads were found in one of two flint deposits, in the upper part of feature 43. Despite the chronology of this feature being determined (based on pottery) as HLS III (hornoslezská lengyelská skupina III), V. Janák argues that these deposits should be instead connected with the Funnel Beaker culture due to the presence of macrolithic flint tools (despite no other traces of FBC occupation recorded). The other of the two sites seems to contain artefacts attributable to HLS IV (JANÁK 1998: 116; 2005: 151, 210, 211).

Another artefact of this kind is a projectile point from Slatina (district Hradec Králové), discovered during a surface survey. It is made of erratic flint, possibly imported from nearby Poland. Its dimensions are $3.7 \mathrm{~cm} \times 1.3 \mathrm{~cm}$. It has sub-lamellar covering retouch, and it is broken so we cannot say whether it was originally symmetrical (С̌̈ЕCHÁK et al. 2017).

The Štramberk type projectile points are also mentioned by J. KOPACZ in his study concerning flint industries of the younger Moravian Eneolithic. In his opinion, one of the arrowheads from a Jevišovice culture site at Grešlové Mýto (Znojmo district), which has a slightly notched base part, reveals a certain similarity to the Štramberk type (KopACZ et al. 2016: fig. 4.2 see also: Kopacz 2012: 30). He indicates that 
artefacts of this type are often connected with the Early Eneolithic or Late Neolithic, but he admits a possibility of their continuation until the Younger Eneolithic.

The presence of Štramberk type projectile points has also been reported in the western part of Slovakia (STRUHÁR 2014 after: ČECHÁK et al. 2017), including in the Slovenské Pravno site (Turčianske Teplice district), where one specimen was found. The site is dated to the Epilengyel phase, but the arrowhead was found outside features and therefore lacks an archaeological context. According to the quoted author it was made of a flint from outcrops situated approx. $25 \mathrm{~km}$ from the site (NevizÁNSKY et al. 2017).

Štramberk-type projectile points are also known from archaeological sites in Poland other than Spytkowice. It is worth mentioning here a grave from Racibórz-Studzienna discovered and described by G. Fock (1941; ChMielewski 2014). It was a single burial, found during rescue excavations. The body was laid in a trapezium-shaped pit and furnished, apart from three Stramberk-type arrowheads, with three pots: a collared flask, a tulip-shaped beaker and an amphora with two handles (with disc-shaped, flattened ends, known as Scheibenhenkel type) slightly rising over the rim (CHMIELEWSKI 2014: 198). T. ChMielewsKi in his article re-analysed and re-dated the grave assemblage, concluding that it belongs to the end of the middle Eneolithic (3650/3600 BC; CHMielewsKi 2014: 206).

Artefacts of our interest also occur in two archaeological sites in Cieszyn Silesia region: in Cieszyn Krasna and Gumna. Rescue excavations on the site of Cieszyn Krasna 14 were conducted by B. and B. CHORĄży (2001, 2002). A total area of 9 ares was excavated at that time, and 17 Neolithic features were found. Due to the presence of characteristic knobs and a ribbon handle bearing some resemblance to the Jordanów materials, the site has been linked with late Lengyel assemblages. Mateusz Mynarski (2013) on the other hand, based on the analysis of the ceramic material, points out a possible connection of the settlement in Cieszyn Krasna with the Modlnica group, which seems very interesting in the context of a similar chronology of the Spytkowice 26 site. Four arrowheads were found in Cieszyn Krasna, among them two examples of the Stramberk type. One of them has edge, semi-flat retouch on both sides. It was made on a blade, with dimensions of $2.7 \mathrm{~cm} \times 1.5 \mathrm{~cm}$. The other is incomplete and was not described by the author of the analysis (Mynarski 2013: 41, pl. XIII: 1, 2). The second mentioned site, Gumna 1 (Dębowiec district), was only examined by a surface survey, also by B. and B. CHORĄży (2001). These materials were also analysed by M. MynaRSKI, who identified two Štramberk type arrowheads and two initial forms (blades with single notches MYNARSKI 2013: pl. II: 1, 4). The projectile points are $3 \mathrm{~cm}$ and $3.5 \mathrm{~cm}$ long; both of them have notches and edge, semi-low-angle retouch, while the initial forms are $2.5 \mathrm{~cm}$ and $3.5 \mathrm{~cm}$ long (MYNARSKi 2013: 46). The chronology of the site was determined by the author as the younger stage of the Lengyel culture (MYNARSKI 2013: 84).

Another artefact of this kind is described by J. RYDLEWSKI and P. VALDE-NOWAK (1979). Found in Paszkówka site 1 (Wadowice district), it is the geographically closest analogy to Spytkowice. It is a tanged point made on a blade removed from an opposite platform core; the dorsal side has semi-abrupt retouch of the top and part of the edge, 
while the ventral part has both low angle and semi-abrupt retouch. The tang, on the other hand, was retouched in the bigger parts with abrupt retouch on the dorsal side and with semi-abrupt retouch on the ventral side. The retouch scars are relatively long and overlapping (P. VALDE-NOWAK, personal information, unpublished). This projectile point has one, slightly marked notch (Fig. 3). The authors of the quoted publication regard this specimen as an analogy to the arrowheads from the above-mentioned grave assemblage discovered in Racibórz-Studzienna. In addition, one of the footnotes in the quoted study mentions the discovery of another similar arrowhead at the Kornice 11 site (Racibórz district; RYDLEWSKI, VALDE-NOWAK 1979: footnote 31).

A tanged projectile point with characteristic side notches was also found at Bronocice. This specimen is $3.6 \mathrm{~cm}$ long, is made of Jurassic flint, and has surface retouch on the notches and both edges, and on the top. The arrowhead was found in a LublinVolhynia culture grave. The authors of the research note its similarity to artefacts of the Neman culture, although in light of the current state of knowledge it should probably be identified as a Štramberk type arrowhead (KRUK, MiLISAUSKAS 1985: 71).

Here it is worth returning to the already quoted article by B. KUFEL-DiAKOwSKA and J. BRONOWICKI (2017). Their analyses were based on 16 specimens of Stramberk type arrowheads from the Upper and Lower Silesia regions. Most of them have bifacial, partially bifacial or edge retouch, although there are also specimens with unretouched tips. Their tangs are shaped mostly with bifacial retouch, less frequently with edge retouch, and they may have straight, oval, or forking ends (sometimes similar to the so-called fish-tail). Apart from the Racibórz Studzienna artefact, there are also five projectile points from Bliszczyce (Głubczyce district, among them four from the site of Bliszczyce 4), one each from Bogdanowice 6, Pietrowice Wielkie 3, and Dolędzina (Racibórz district), and one from Zubrzyce 9 (Głubczyce district). All of them unfortunately are stray finds. Moreover, two of them were found in FBC features (Bielawa 12, Dzierżoniów district, Grodziszcze 7, Świdnica district), one beneath an FBC barrow (Muszkowice 18, Ząbkowice district) and one nearby an FBC pottery concentration (Ślęża 26, Wrocław district). One is particularly interesting as it was found in a grave linked with the Chłopice-Vesele culture (i.e. the early Mierzanowice culture according to current views).

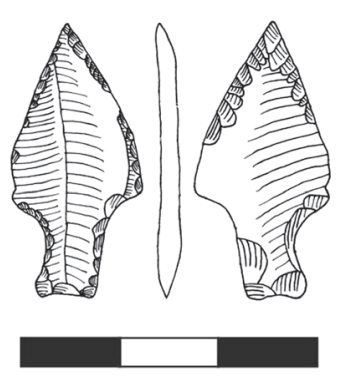

Fig. 3. Štramberk type arrowhead from Paszkówka 1 (Wadowice district). Drawing based on the private archive of P. Valde-Nowak 


\section{The chronology of the Stramberk arrowheads}

To describe the phenomenon of Eneolithic flint arrowheads it is especially worth referring to J. LIBERA's study 'Krzemienne formy bifacjalne na terenach Polski i zachodniej Ukrainy (od środkowego neolitu do wczesnej epoki żelaza)" ("Flint bifacial forms in Poland and West Ukraine (from the middle Neolithic to the early Iron Age")), which catalogues this kind of flint artefact from the area of Poland. The author collected a significant number of projectile points made using the method of bifacial retouch and he came to some conclusions considering their chronology. Among others, Libera presents the history of research on the issue, referring to different typologies (LIBERA 2001: 19-21) and developing his own one. He connects the beginning of mass occurrence of arrowheads with the middle Neolithic, primarily with the Lublin-Volhynia culture, where mostly forms in the shape of equilateral and isosceles triangles appear, with trough-like retouch. He also notices the uniqueness of the specimen from Bronocice, described above. A wider variety begins with the FBC when, along with triangular forms (e.g. Stara Wieś), tanged arrowheads also appear in grave inventories (i.e. Pikutkowo), and analogical specimens appear in settlement contexts in Kuyavia and Greater Poland. Libera regards the above-described finds from Racibórz-Studzienna as "totally different forms". In his opinion the tanged points from the early stages of FBC mark the earliest horizon of tanged arrowheads in the described area (Poland and western Ukraine; LIBERA 2001: 90).

In light of the facts presented in this article this view should perhaps be slightly corrected. Artefacts of this kind are known from late Lengyel sites near Cieszyn and from Spytkowice, and they all can be classified as the Stramberk type. In terms of absolute chronology these sites were probably earlier than the early FBC, at least in Lesser Poland and Upper Silesia (Mynarski 2013; ChOrĄży, Chorąży 2002; BrzesKa-PASEK et al. 2018). One should also bear in mind the triangular projectile point from feature 44 in Spytkowice. This shape is quite common and is often associated with the Lublin-Volhynia culture, finding analogies in the FBC as well (LIBERA 2001), although we should keep in mind that feature 44 has been interpreted as belonging to the Modlnica group.

The three arrowheads from Spytkowice 26 are part of a broader horizon of occurrence of the Štramberk type projectile points. There are many opinions in the literature in regard to the provenance of the artefacts of this kind. Among others, J. Kopacz points to analogies from the milieu of the Gumelniţa culture (KopaCz 2012: 30), although such a distant analogy seems a little bit risky, at least until some similar artefacts are found in the cultures of the early and middle Eneolithic in the Carpathian Basin. A publication concerning the Lublin-Volhynia culture settlement in Bronocice presents a discussion of an arrowhead of the Štramberk type discovered there, with the authors emphasising its similarity to analogical artefacts known from the Neman culture (KRUK, MiLISAUSKAS 1985: 71). Following the analysis of materials from Racibórz-Ocice (KozŁowsKI 1972), J. RYDLEWSKI and P. VALDE-NowAK (1979: footnote 31) regard the specimen from Paszkówka as evidence for influence of the Chassey or Michelsberg cultures. The issue has also been addressed by T. CHMIELEWSKi (2014: 201), who noticed that such a genesis of the Stramberk type arrowheads continued to be suggested in the publications even at 
the beginning of the 21 st century despite it being known by that time that in Silesia and Moravia the artefacts in question have earlier chronology. He points out that arrowheads were often prepared in an opportunistic way by simply shaping the tang and the point on a blade or a blade-like blank; they were not necessarily bifacially retouched, and the form could as well have developed locally. It seems that in fact the general problem with culturally-chronological classification of the Stramberk type arrowheads, among them the ones described in this article, lies in the lack of any evident, or at least relatively homogeneous, context of their discovery.

In light of the finds discussed above, it can be noticed that they occur in the late Lengyel-Polgar context as well as throughout the entire period of existence of FBC. There are also single finds known from the context of the Jevisovice culture and even the Chłopice-Vesele culture (i.e. the early Mierzanowice culture according to current views). However, given the very limited number of finds from such late contexts, it is necessary to ask whether the similarity of these artefacts to the Stramberk type is not just coincidental. Arrowheads of the Stramberk type should be seen as an intercultural element, created probably in the late Lengyel milieu and somehow "inherited" by later communities, e.g. of the Funnel Beaker culture. To be on the safe side we should add that in the case of Spytkowice there is information in the literature that some of the pottery originating from S. DRYJA's research reveals characteristics possibly linkable with the later Wyciąże-Złotniki group. However, to tell the truth the same traits (e.g. the characteristic "cut-off" belly) occasionally occur in the (Pleszów-)Modlnica group as well (BRZESKA-PASEK et al. 2018: 147). Such a chronological shift of the arrowheads from Spytkowice would allow them to be correlated in time with the earliest finds from the Czech Republic, which V. Janák connects with HLS IV (JANÁK 1998: 116; 2005: 151; 2007: 146-149).

\section{CONCLUSIONS}

The three Štramberk type arrowheads from Spytkowice fit into a wider horizon of tanged projectile points with notches. These artefacts, alongside the specimens from Cieszyn Krasna and Gumna, may be seen as possibly the earliest finds of this kind (MyNARSKI 2013). Their existence starts in late Lengyel culture and lasts maybe even until the early Bronze Age. Geographically they occur from the western part of Silesia and Czech Republic to Lesser Poland in the east. Macroscopic traces found on the projectile points from Spytkowice indicate that they may have been damaged by impact, but to prove that they were really used as a throwing weapon a traseological analysis would be required.

ACKNOWLEDGEMENTS. I would like to express my gratitude to several persons that contributed to the return of archaeologists to Spytkowice, and thus to the creation of this article. In the first place I would like to thank Magdalena Moskal del-Hoyo, PhD, whose project "Szukajac dpowiedniego miejsca na zamieszkanie: gospodarka roślinna I wzajemne interakcje człowiek-środowisko na początku okresu neolitycznego w Matopolsce" ["Searching for a suitable place to settle down: the plant economy and human-environment 
interactions at the beginning of the Neolithic period in Małopolska (Poland)"] (2018/30/E/HS3/00867), financed by NCN (The National Science Centre in Poland), made it possible to conduct field research and the analysis of materials that were found in Spytkowice 26. Next, I would like to thank Prof. Pawel Valde-Nowak for his help in the first interpretation of the described artefacts and for information about analogical artefacts from Paszkówka and Kornice, and Prof. Marek Nowak for his huge help during our excavations and during preparation of this article. I would also like to express my gratitude to Prof. Agnieszka Czekaj-Zastawny, Małgorzata Kaczanowska, PhD, and Prof. Janusz K. Kozłowski, who helped us with their knowledge and experience during the excavations in Spytkowice. I would also like to express my gratitude to M. Korczyńska and P. Kowalczyk-Matys for information about the chronology of the features excavated in Spytkowice.

\section{REFERENCES}

Brzeska-Pasek A., Kenig R., Oberc T., Nowak M., 2018. Wczesnoneolityczne osady w Spytkowicach i ich rola w dystrybucji krzemienia jurajskiego. Acta Archaeologica Opaviensia 5: 139-164.

Chmielewski T. J., 2014. Unknown knowns. Eneolithic findings from Kietrz-Łęgi and Racibórz-Studzienna. Acta Archaeologica Academiae Scientiarum Hungaricae 65: 177-216

Chorąży B., Chorąży B., 2001. Nowe odkrycia osiedli neolitycznych na terenie Pogórza Cieszyńskiego. Neolit i początki epoki brązu w Karpatach polskich. Krosno: 343-356.

Chorąży B., Chorąży B., 2002. Sprawozdanie z ratowniczych badań wykopaliskowych na stanowisku 14 w Cieszynie-Krasnej, województwo śląskie. Badania archeologiczne na Górnym Śląsku i ziemiach pogranicznych w latach 1999-2000. Śląskie Centrum Dziedzictwa Kulturowego. Katowice: 95-105.

Č̈енÁ́ P., HerČík O., Suchopárová K., 2017. Ojedinělý nález šipky typu Štramberk ze Slatiny. Archeologie východních Čech 13: 119-126.

DRYJA S., 1997. Spytkowice 26, gm. loco. Informator Archeologiczny, badania, rok 1992: 18.

DRYjA S., 1998a. Spytkowice 26, gm. loco. Informator Archeologiczny, badania, rok 1993: 21.

DrYja S., 1998b. Spytkowice 26, gm. loco. Informator Archeologiczny, badania, rok 1994: 23.

DRYJA S., 1998c. Spytkowice 26, gm. loco. Informator Archeologiczny, badania, rok 1995: 23.

DRYJA S., 1998d. Pierwsze znalezisko wczesnoneolitycznych przekłuwaczy typu Vedrovice z ziem polskich Sprawozdania Archeologiczne 50: 141-148.

DRYJA S., 2005. Spytkowice 26, gm. loco. Informator Archeologiczny, badania, 1996: 69-70.

Fock G., 1941. Tulpenbecher und Kragenflasche aus einem jungsteinzeitlichen Grab von Ratibor-Süd. Nachtrichtenblatt für Deutsche Vorzeit, 17: 37-39.

JANÁK V., 1998. Lengyelská keramika z Kotouče u Štramberka a počátky eneolitu v oderské části Moravské brány. Pravěk Nová řada 7(1997): 105-127.

JANÁK V., 2005. Nástup eneolitu v českém Slezsku (hornoslezská lengyelská skupina a kultura nálevkovitých pohárů). Typescript of habilitation thesis. Opava.

JANÁK V., 2007. Př́spěvek neolitické a eneolitické štípané kamenné industrie k poznání sociálních a hospodářských poměrůsvé doby na př́kladu Horního Poodří. In: Kazdová E., Podborský V., (Eds) Studium sociálních a duchovních struktur pravěku (Studium der sozialen und geistlichen Strukturen der Urzeit). Eds. Brno: 37-179.

KLIMA B., 1962. Pozdně paleolitická stanice na Kotouči ve Štramberku. Antropozoikum 10(1960), 63-112.

Kopacz J., 2012. Koncepcja krzemieniarstwa schyłkowego na przykładzie eneolitu moraw. Przegląd Archeologiczny 60: 25-47. 
Kopacz J., Přichystal A., Šebela L., 2016. Forerunners of the new epoch in lithic chipped industries of the moravian young eneolithic. Musaica Archaeologica 1: 105-118.

KozŁowski J. K., 1972. Wielokulturowe stanowisko eneolityczne w Raciborzu-Ocicach w świetle badań lat 1960-1962. Rocznik Muzeum Górnośląskiego 10: 77-187.

Kruk J., Milisauskas S., 1985. Osiedle obronne ludności kultury lubelsko-wołyńskiej /2800-2700 lat p.n.e./. Wydawnictwo PAN.

Kufel-Diakowska B., Bronowicki J., 2017. Problem użytkowania eneolitycznych grotów trzoneczkowatych w świetle materiałów z terenów Górnego i Dolnego Śląska. Śląskie Sprawozdania Archeologiczne 59: 19-47.

Libera J., 2001. Krzemienne formy bifacjalne na terenach Polski i zachodniej Ukrainy (od środkowego neolitu do wczesnej epoki żelaza). Wydawnictwo Uniwersytetu Marii Curie-Skłodowskiej, Lublin.

MyNARSKi M., 2013. Neolityczne kultury kręgu naddunajskiego w zachodniej części polskich Karpat i ich przedpola. Typescript of master thesis, IA UJ.

NevizÁnsky G., ŠAlkovský P., ZaChar T., 2017. Archeologický výskum v slovenskom pravne. Príspevok $\mathrm{k}$ poznaniu metalurgie medi v obdobíe neolitu. Zborník slovenského národného múzea v Martine, kmetianum 14: 37-47.

Pelisiak A., GęBica P., 2007. Podstawy geomorfologii i gleboznawstwa: (dla archeologów). Rzeszów.

RYDLEWSKi J., VAlDE-NowAK P., 1979. Problem osadnictwa epoki kamienia w polskich Karpatach zachodnich w świetle badań na polskiej Orawie i w rejonie prawobrzeżnych dopływów górnej Wisły. Acta Archaeologica Carpathica 19: 5-36.

SANo K., 2009. Huting evidence from stone artefacts from the Magdalenian cave stie Bois Laiterie, Belgium: a fracture analysis. Quartär 56: 67-86.

SCHIRMEISEN K., 1936. Neuere Vorgeschichts funde auf dem Burg-und dem Schellen burgberg bei Jägerndorf. Verhandlungen des naturforschen den Vereines in Brünn 67/1935: 138-148. Brünn.

StruHÁr V., 2014. Contrubution to the problems of occurrence of erratic Side Notched Arrowheads („,Kerbespitze“) in Eneolithic cultures. International Symposium „Centenary of Jaroslav Palliardi's Neolithic and Aeneolithic Relative Chronology" and XXXIIIrd Conference on the Neolithic and Aeneolithic our countries. Moravské Budějovice, Monday 15th - Thursday 18th September 2014. Programme, Book of abstracts. 2014. Moravské Budějovice, 26-27.

STRYjKowska M., 2010. Materiały z badań przeprowadzonych w 1993 roku na stanowisku Spytkowice 26. Materiały i Sprawozdania Rzeszowskiego Ośrodka Archeologicznego 31: 29-38.

Šı́ulová V., ZÁротоскÝ M., 2010. Rane eneoliticky medeny pektoral z vrchu Kotouč u Štramberk. Archeologicke rozhledy 62: 395-428.

VENCL S., 1964. K otazce datování sídliště na temeni vrchu Kotouče ve Štramberku. Acta Musei Moraviae 49: 49-60. 